\title{
Spiritual-based relapse prevention program in community setting
}

\section{Short communication}

Spiritual based SUD treatment and prevention program has been widely accepted though it is not strongly evidenced-based. In many developing countries, especially with the Muslim, Hindu, Buddhist and many others, this practice is common. This short article is based on observational study to share the outcome of an Islamic based program in Malaysia.

When recovering drug users left the institutional drug treatment program, most of them still need guidance to maintain abstinence and re-enter their society. ${ }^{1-3}$ Many will use the government facilities, such as the Drop-In and Community Service Centres and other Community-based programs to gain the confidence and prevent relapse. There are a multitude of programs that they can follow, one of which is the spiritual and religious program..$^{5-7}$ (Table 1).

For the Islamic program practiced in many Islamic countries including Malaysia, most of the community-based program also contains the followings:

a. Taqwa (faith) enhancement program.

b. Solat (prayers) program.

c. Capacity building and enhancement.

d. Spiritual and religious recovery mentoring.

e. Visits of the community religious leaders.

f. Dakwah (religious teaching) methodology courses. These were often done with collaboration of the local religious heads in the community. ${ }^{8-10}$

Table I Some of the Community-Based Islamic Programs and its Expected Outcomes

\begin{tabular}{|c|c|c|}
\hline No. & $\begin{array}{l}\text { Program/ } \\
\text { activities }\end{array}$ & Objective \\
\hline I & Halaqah & $\begin{array}{l}\text { Provide continuous religious classes to } \\
\text { recovering drug addicts and their families, } \\
\text { besides group meetings to enhance recovery }\end{array}$ \\
\hline 2 & $\begin{array}{l}\text { Islamic art and } \\
\text { culture }\end{array}$ & $\begin{array}{l}\text { Provide Islamic entertainment, arts and } \\
\text { culture for recovering drug addicts }\end{array}$ \\
\hline 3 & Ibadat camp & $\begin{array}{l}\text { To provide an intensive program to study } \\
\text { Fardhu 'Ain \& Fardhu Kifayah to recovering } \\
\text { drug addicts }\end{array}$ \\
\hline 4 & $\begin{array}{l}\text { Mosque as foster } \\
\text { parents }\end{array}$ & $\begin{array}{l}\text { To aid recovering drug addicts and their } \\
\text { families in the recovery process by using the } \\
\text { spiritual approach }\end{array}$ \\
\hline 5 & $\begin{array}{l}\text { Friends of the } \\
\text { mosque }\end{array}$ & $\begin{array}{l}\text { To encourage recovering drug addict to be } \\
\text { close to the mosque institution. It can act } \\
\text { as a temporary shelter for them when they } \\
\text { re-enter the community }\end{array}$ \\
\hline 6 & $\begin{array}{l}\text { Volunteer work } \\
\text { in the community } \\
\text { mosque }\end{array}$ & $\begin{array}{l}\text { To encourage recovering drug addicts to } \\
\text { contribute back to the society besides } \\
\text { preparing them to be reintegrated back into } \\
\text { the community }\end{array}$ \\
\hline 7 & $\begin{array}{l}\text { Outreach to other } \\
\text { drug addicts }\end{array}$ & $\begin{array}{l}\text { Outreach work to recovering or drug } \\
\text { addicts \& families in the community }\end{array}$ \\
\hline
\end{tabular}

What is the outcome of these religious inputs? Malaysian National AntiDrug Agency, ${ }^{2,10}$ in its implementation documents stated that the desired outcomes would be clients that perform social and religious practice in their everyday life; clients practice Islam as a way of life; religion can deviate
Volume 5 Issue 3 - 2018

\author{
Mahmood Nazar Mohamed,' Sabitha \\ Marican $^{2}$ \\ 'Asia Metropolitan University and Cyberjaya University College \\ of Medical Sciences, Malaysia \\ ${ }^{2}$ University Malaya, Malaysia
}

Correspondence: Mahmood Nazar Mohamed, Professor of Psychology, Asia Metropolitan University and Cyberjaya University College of Medical Sciences, Malaysia,Tel +60124776710,Email mahmoodnazar@gmail.com

Received: April 21, 2018 | Published: June 13,2018

clients away from negative life influences and decisions; there are some improvements on the clients' physical, emotional social and spiritual quality of life. The question is how to measure these outcomes in a short time frame.

This study conducted at 10 Community-Based Cure and Care Service Center (CCSC) showed that there are positive changes perceived by the clients after they undergo at least 12 months of religious programs using three rehabilitation models as part of their rehabilitation. ${ }^{4}$ (Table 2).

Table 2 Measuring outcomes at 10 CCSCs

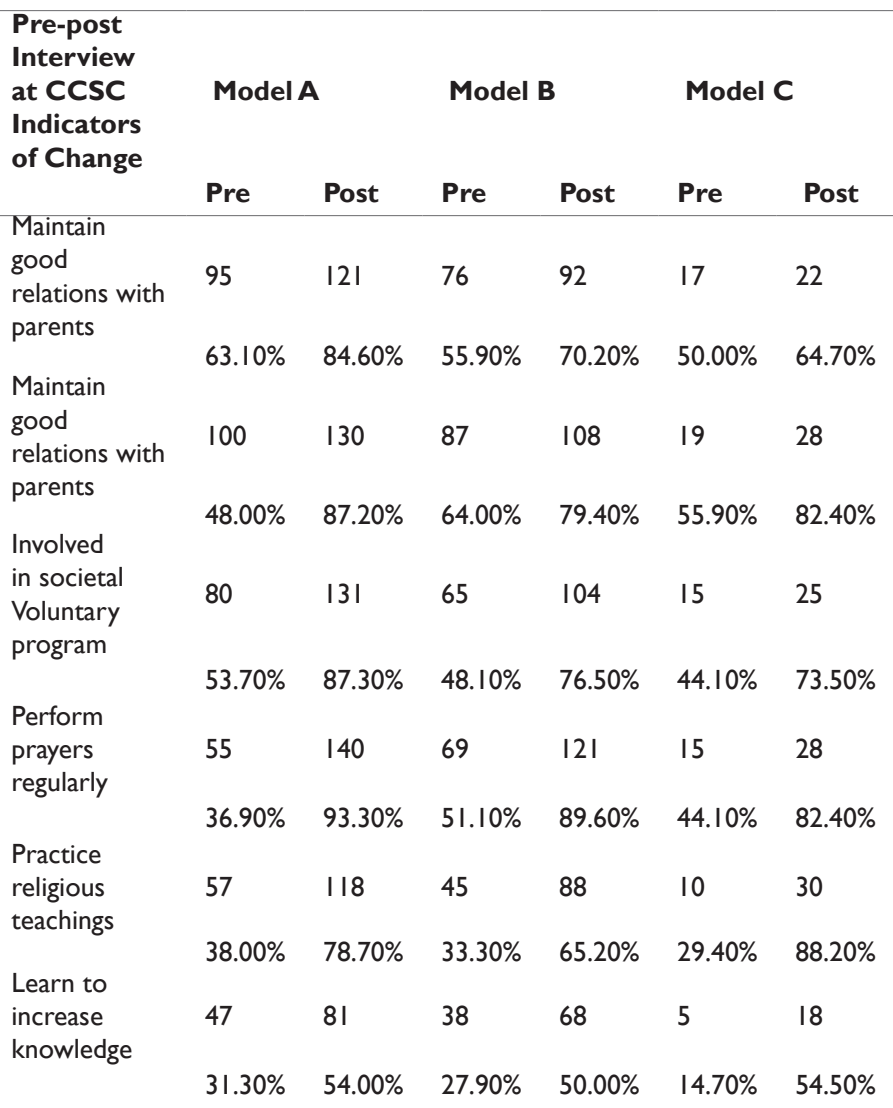


Model A is the program operated by government officers; the programs at model $\mathrm{B}$ are being operated by government and NGOs; and Model C programs are operated by NGOs. Almost in all models, there have been positive changes on many indicators. Specifically, religious indicators such as "perform prayers regularly" and "practice religious teachings" saw the largest and significant perceived change, respectively from $36 \%$ to $93 \%$ and $29 \%$ to $88 \%$. Most of the religious programs are being conducted by religious officers and these positive perceptions among residents can attribute to its positive outcomes. ${ }^{4}$ The occurrence of relapse is also reduced.

\section{Conclusion}

the inclusion of religion and spirituality into drug treatment has been found to have positive effect in preventing relapse among residents and clients. Outcomes such as increase in church attendance that was associated with reduction in cocaine use, ${ }^{11}$ to regularly performance of one's religious obligations, ${ }^{5}$ such a positive effect, though not widespread has help to improve the quality of life of recovering drug addicts. ${ }^{4}$ There are studies that showed good outcomes to the religious programs conducted in Malaysia; however, there are also studies that showed little change over a longer period of time., ${ }^{71}$ These studies also pointed out spiritual and religious inputs must be conducted together with other evidence-based drug treatment modalities. Those who conduct the religious program in isolation have shown to be of little effect, ${ }^{11}$ as compared to those conducted with other programs such as detoxification, behavioural interventions, therapeutic communities and others.

\section{Acknowledgements}

This short report is produced based on a study supported by the National Anti-Drug Agency, Malaysia.

\section{Conflict of interest}

The author declares no conflict of interest.

\section{References}

1. NIDA. Principles of drug addiction treatment: A research-based guide. National Institute on Drug Abuse, National Institutes of Health, U.S Department of Health and Human Services, USA; 2009.
2. National Anti-Drugs Agency. 10 years statistics of Drug Use in Malaysia: 1995-2006. Malaysia, Putrajaya: NADA; 2007.

3. Mahmood NM. Drug situation in Malaysia: Trends, incidences and antidrug strategies. Indian J Psychol. 2012; Special Issue:71-82.

4. Mahmood NM. Sabitha M. Positive outcomes of Cure and Care Service Centers (CCSC): A community-based treatment program in Malaysia, International Journal of Prevention and Treatment of Substance Use Disorder. 2014;1(2):71-83.

5. Gorsuch RL. Religious aspects of substance abuse and recovery. Journal of Social Issues. 1995;51(2):65-83.

6. Miller WR. Integrating spirituality into treatment. Washington, American Psychological Association; 1999: 293 p.

7. Pardini DA. Plante TG. Sherman A, et al. Religious faith and spirituality in substance abuse recovery: Determining the mental health benefits. $J$ Subst Abuse Treat. 2000;19(4):347-354.

8. Malik Ghulam Farid. The Holy Quran, Arabic Text With English Translation \& Short Commentary. Islam International Publications Limited. 2017;5:91-92.

9. Narrated Ibn 'Umar, Narrated Abu Huraira, Narrated Anas, et al. Drinks. Book 69, Translation of Sahih Bukhari. Vol 7:481-494.

10. National Anti-Drug Strategy: Annual Performance Report 2012-13. Malaysia, Bangi, NADA; 2012.

11. Richard AJ, Bell DC, Carlson JW. Individual Religiosity, Moral Community, and Drug User Treatment. Journal for the Scientific Study of Religion. 2000;39(2):240-246. 